Original Research Paper

\title{
Some Features of Rice Cultivation Agrotechnics in Kazakhstani Aral Sea Region
}

\author{
${ }^{1}$ Zhazira Baiserikovna Zhumatayeva, ${ }^{2}$ Asset Myrzakhanuly Toktamyssov, ${ }^{2}$ Kurmanbek Bakiruly, \\ ${ }^{3}$ Murat Orlenbaevich Nassimov and ${ }^{4}$ EImira Shoraevna Yeleuova \\ ${ }^{1}$ Kazakh National Agrarian University, Almaty, Kazakhstan \\ ${ }^{2} Z$ Zhakhaev Kazakh Research Institute of Rice, Kyzylorda, Kazakhstan \\ ${ }^{3}$ University Bolashak, Kyzylorda, Kazakhstan \\ ${ }^{4}$ Korkyt Ata Kyzylorda State University, Kyzylorda, Kazakhstan
}

Article history

Received: 15-05-2017

Revised: 02-06-2017

Accepted: 10-06-2017

Corresponding Author: Murat Orlenbaevich Nassimov University Bolashak, Kyzylorda, Kazakhstan Email: nasimov_m@mail.ru

\begin{abstract}
The article presents the results of a study of high quality agrotechnics that allowed to use Marzhan, Yantar and AySaule rice varieties under the stress conditions of Kazakhstani Aral Sea region. In particular, the different seeding rate of seeds of rice $(6.5,7.0$ and 7.5 million of germinating seeds per hectare) and application rates of the main types of mineral fertilizers (without fertilizers, $\mathrm{N}_{90} \mathrm{P}_{90} . \mathrm{N}_{90+30} \mathrm{P}_{90}$. $\mathrm{N}_{120} \mathrm{P}_{90} \mathrm{~K}_{60}$ ) were examined. All studied varieties responded favorably to fertilizers. At the same time, the productivity of Marzhan grade was increased from 2.91 to $6.91 \mathrm{t} / \mathrm{ha}$, grade Yantar from 2.75 to $7.10 \mathrm{t} / \mathrm{ha}$ and grade AySaule from 3.16 to 7.28 t/ha. However, higher doses of fertilizer led to a strong lodging of Marzhan varieties. Learned seeding rate had a significant effect on plant density. So, with a decrease of rice seeding rate the number of plants were reduced before harvesting in grade Marzhan for 18\%, grade Yantar 23\% and grade AySaule 17\%. To obtain the highest yield variety of rice sown Yantar should be the norm of 7.0 million germinating seeds per hectare on the background of $\mathrm{N}_{90+30} \mathrm{P}_{90}$, for grades AySaule the best conditions are created at 7.5 million germinating seeds per hectare and $\mathrm{N}_{90+30} \mathrm{P}_{90}$, Marzhan 6.5 million germinating seeds per hectare and $\mathrm{N}_{90+30} \mathrm{P}_{90}$.
\end{abstract}

Keywords: Variety, Rice, Seed Rate, The Dose of Fertilizer, Productivity

\section{Introduction}

Rice is the most important food crop in the world cultivated on 153500000 hectares in 115 countries. More than 3 billion people are fed by rice and the needs of more than $30 \%$ of food calories are met. It contains $73-81 \%$ of carbohydrates, $6-9 \%$ protein, $0.6-0.2 \%$ fat, $0.8-2.0 \%$ ash, $0.2-1.0 \%$ dietary fiber, vitamins. Rice protein is rich in lysine, valine, methionin and other essential amino acids. Rice cereal is more valuable dietary product; it has a high nutritional value. Chaff and scrap, resulting from the processing of paddy rice, are used to produce alcohol, special varieties of vodka (sake), beer and starch, which is used in the aerospace industry for the production of rice powder (Sheudzhen et al., 2001). Consumer demand for rice is increasing every year and by the Food and Agricultural Organization (FAO) forecast, by 2020 it will amount to 781 million tons, exceeding 2-3\% demand for wheat.

In Kazakhstan, rice is actually cultivated on the northern limit of the spread of culture $\left(43-44^{0}\right.$ average scale). Total acreage is 92-100 thousand hectares; more than $80 \%$ of the areas are located in the lower reaches of the Syr Darya River in Kazakhstani Aral Sea region. Local high-yielding middle matured varieties with the potential productivity of 6-8 $\mathrm{t} / \mathrm{ha}$ are zoned in the region.

Rice Challenges in Kazakhstani Aral Sea region lies in the fact that this rice-growing region is different from the rest with its sharply continental climate and significant soil salinity.

The problem of infection fungal diseases of rice crops previously was almost absent due to the dry climate in the region. However, in recent years, fungal diseases, including the blast disease, are increasingly begun to appear in the rice crops.

Therefore, their resistance to diseases and pests is also becoming increasingly important in the breeding and introduction of new varieties. In this regard modern varieties must be resistant to biotic and abiotic environmental factor together with high productivity potential. Earlier varieties of local selection, characterized by its high productivity and significant 
resistance to abiotic stressors, do not have sufficient resistance to diseases and pests of rice.

In addition, rice varieties that meet international standards and meet the needs of many different users need to export rice products to the foreign market (TCVRBI, 2007).

Rice grain quality is generally classified into four major physical and chemical indicators, i.e., appearance quality (grain length, grain width, length/width ratio and chalky grains) milling quality (brown rice yield and milled rice yield), cooking and edibility characteristics (amylose content) and nutritional quality (protein content). (Koutroubas et al., 2004; Li et al., 2004). Rice (Oryza Sativa L.) is a major component of the diet in most countries. It is highly consumed in Asia and Africa and to a lesser extent in the European Union (Vlachos and Arvanitoyannis, 2008).

Many factors influence on the productivity of crops: Soil and climatic conditions, soil tillage methods, timing and methods of sowing and many others (Khatkov, 2009). In the rice cultivation the water layer availability on the field surface smoothes out soil and air temperature fluctuations. So, the rice productivity does not depend on the amount of precipitation and high air temperatures less influence on its development. However, the air temperature is the deciding factor in choosing a time of sowing of this crop. To begin the sowing of rice is possible only with a stable average daily air temperature of $10^{\circ} \mathrm{C}$. According to most researchers, the average optimal temperature for the germination of rice seeds and seedling emergence through $10-15$ days is $12-15^{\circ} \mathrm{C}$, when the temperature of the soil and water to the experimental plots reaches $14-16^{\circ} \mathrm{C}$ (Agarkov et al., 2006; Iskhakov, 1969; Kirichenko, 1944; Aleshin and Aprod, 1960). If we sow the rice earlier germination capacity would be reduced significantly (Kirichenko, 1944).

Rice is grown on irrigated land only on the technology, which differs from other cultures. Its feature is to provide a permanent, shortened or periodic flooding of rice fields' layer of water. The need for such a method is determined not so much by biological characteristics of this culture, as the need to deal with weeds, primarily corn bunting (Velichko and Shumakova, 1972; Witte, 1930; Dzhulay, 1956; Erygin, 1950; Kruzhilin et al., 2005).

As any soil has water permeability, the structure of the water flow from the flooded checks, in addition to transpiration and evaporation, a significant proportion accounted for filtering. The cultivation of rice in the traditional technology of the cost of irrigation water per 1 hectare of its crops, depending on the environmental conditions is between 15 and 25 thousand $\mathrm{M}^{3}$ and more and biological need is 7-9 $\mathrm{M}^{3}$ (Velichko and Shumakova, 1972; Kruzhilin et al., 2005). The rest of the water used for irrigation is spent for soil salt and a decrease in mineralization of irrigation water, for surface evaporation from the surface of water and transpiration of plants and for the creation of a microclimate in crops under high air temperatures.
All this increases the cost of construction and operation of irrigation systems. In addition, water not used for transpiration and evaporation, replenishing ground water degrades the reclamation of irrigated and adjacent land, negative impact on the environment, necessitates the construction of the drainage network. Retraction from rice systems with a large number of mineralized and contaminated by herbicides and drainage discharge water fertilizers creates a serious problem for its utilization (Velichko and Shumakova, 1972; Kruzhilin et al., 2005).

However, achieving the potential productivity in the local soil and climatic conditions is not always possible due to weak study of the physiological and biological characteristics of the new varieties. Therefore, the study of the variety of factors and specific use of crop formation seem urgent. An analysis of the scientific literature on the subject shows the great dependence of the yield of the genetic characteristics of certain methods cultivation varieties and management of soil fertility.

The aim of our research is an assessment of crop structure parameters of new rice varieties zoned local selection and optimization of plant nutrition by using the calculated doses of mineral fertilizers.

\section{Materials and Methods}

Investigations were carried out in 2016 in the small plot field three-factor experiment, followed by observations of plant development and appropriate records. The experiment was conducted by Karaultyube Pilot Production Organization of I. Zhakhaev Kazakh Research Institute of Rice.

The climate of region is sharply continental, hot, dry summer and cold winter with unstable snow cover. The average annual air temperature is $9.8^{\circ} \mathrm{C}$. The climate is very dry. The average annual rainfall is $129 \mathrm{~mm}$. In some dry years they can fall just 40-70 $\mathrm{mm}$.

Soil of experimental ground is meadow and marsh, typical for rice field crop rotations. It is characterized by low humus content up to $1 \%$ of low porosity and relatively high value of the solid residue of $0.6-0.8 \%$. Salinity type is chloride-sulfate (Table 1).

Soils rice systems of Kazakhstani Aral Sea region is characterized by low fertility, so any culture cultivated in the region responds well to the introduction of nitrogen and phosphate fertilizers.

The research was carried out by conventional certified methods. Modern methods of chemical analysis were used for the agrochemical analysis of soil, plant and water and the composition of salt in the aqueous extracts.

April and May months were rainy during the year of account, precipitation was 2.1 times more than the average annual values.

In June, the average daily temperature values were 27.1 , that was $+1.1^{\circ} \mathrm{C}$ higher than year averages, the maximum temperature rose to $40.3^{\circ} \mathrm{C}$, which is higher than normal nearly $6^{\circ} \mathrm{C}$ (Table 2 ). 
Table 1. Indicator of the experimental section soil

\section{Contents}

\begin{tabular}{lllllll}
$\begin{array}{l}\text { Horizon of } \\
\text { soil, } \mathrm{cm}\end{array}$ & $\begin{array}{l}\mathrm{Ph} \\
\text { salt extraction }\end{array}$ & $\begin{array}{l}\text { Humus, } \\
\%\end{array}$ & $\begin{array}{l}\text { Total nitrogen } \\
\%\end{array}$ & $\begin{array}{l}\text { Gross phosphorus, } \\
\%\end{array}$ & $\begin{array}{l}\text { Easily hydrolysable } \\
\text { nitrogen } \mathrm{mg} / \mathrm{kg}\end{array}$ & $\begin{array}{l}\text { exchange potassium } \\
\mathrm{mg} / \mathrm{kg}\end{array}$ \\
\hline $0-10$ & 7.67 & $0.9-1.0$ & 0.08 & 0.13 & 27.3 & 150.9 \\
$10-20$ & 7.69 & $0.7-0.8$ & 0.06 & 0.11 & 23.3 & 143.7 \\
\hline
\end{tabular}

Table 2. Agro-climatic indices, 2016

\begin{tabular}{|c|c|c|c|c|c|c|}
\hline \multirow[b]{2}{*}{ Months } & \multicolumn{3}{|c|}{ Average daily air temperature, ${ }^{\circ} \mathrm{C}$} & \multicolumn{3}{|c|}{ Precipitation $\mathrm{mm}$} \\
\hline & $\begin{array}{l}\text { Mid } \\
\text {-month }\end{array}$ & $\begin{array}{l}\text { Medium- } \\
\text { long-term }\end{array}$ & $\begin{array}{l}\text { the deviation from } \\
\text { mid-long-term, +- }\end{array}$ & Monthly & $\begin{array}{l}\text { Medium- } \\
\text { long-term }\end{array}$ & $\begin{array}{l}\text { The deviation from } \\
\text { mid-long-term, +- }\end{array}$ \\
\hline April & 14.8 & 13.3 & 1.5 & 47 & 16 & 31 \\
\hline May & 21.3 & 20.3 & 1.0 & 27 & 16 & 11 \\
\hline June & 26.5 & 26.1 & 0.4 & 18 & 10 & 8 \\
\hline July & 29.4 & 27.8 & 1.6 & 0 & 6 & -6 \\
\hline August & 27.9 & 26.5 & 1.4 & 18 & 16 & 2 \\
\hline September & 20.6 & 18.6 & 2.0 & 0 & 4 & -3 \\
\hline
\end{tabular}

The rice varieties, accepted to use Marzhan (control), Yantar and AySaule, were grown in the experiment. Seeding rate is $6.5 ; 7.0$ and 7.5 million germinating seeds per hectare. Doses of fertilizers are calculated by the amendments to the average recommended based agrochemical soil conditions and on the removal of nutrients from the crop yield $8 \mathrm{t} / \mathrm{ha}$. In the experiments, they were respectively with no fertilizer: $\mathrm{N}_{90} \mathrm{P}_{90} . \mathrm{N}_{90+30} \mathrm{P}_{90} . \mathrm{N}_{120} \mathrm{P}_{90} \mathrm{~K}_{60}$.

The total area of the plot is $50 \mathrm{~m}^{2}$, protective strips on each side $0.5 \mathrm{~m}$, repeated three times, the location of the plots is randomized. Accountings for harvest was carried out by mechanized way using a mini combine Khazar accompanied by a biometric analysis.

The results were subjected to statistical processing method of Dospehov (1973).

\section{Results and Discussion}

AySaule grade provided the greatest yield. In a fertilizer dose version, designed for removal of a harvest it was close to a programmable $7.28 \mathrm{t} / \mathrm{ha}$, while the average for the experience on $5.77 \mathrm{t} / \mathrm{ha}$. The seeding rate has little effect on grain yield with a tendency to increase at a denser planting.

The addition from its increase from 6.5 to $7.5 \mathrm{mln}$ pcs germinating seeds per hectare was on $0.08-0.50 \mathrm{t} / \mathrm{ha}$. The greatest effect was obtained from the fertilizers and the yields on all sorts increased with increasing doses of $2.91 \mathrm{t} / \mathrm{ha}$ in control $7.28 \mathrm{t} / \mathrm{ha}$ with high dose calculation version. A combination of factors (variety and seed rate) provided a marginal increase in favor of a higher seeding rate of AySaule (0.27 t/ha) and Yantar (0.64 t/ha) varieties or crop reduction of Marzhan (0.33 t/ha). Significant addition was noted with the combination of factors (variety and fertilizer) on all grades (Marzhan 2.90-3.78 t/ha, Yantar 3.66-3.84 t/ha, AySaule 3.41-3.94 t/ha) directly dependent on the doses of fertilizers. The effect of the interaction between factors (seeding rate and fertilizer) was low, at the level of $0.43-0.56 \mathrm{t} / \mathrm{ha}$, mainly dose of fertilizer provided yield increase. Seeding rate had an impact on the level of the trend, but it had an effect on the structure of the crop (Table 3).

According to the literature data and practice, it has been proved the advantage of fractional application of nitrogen fertilizers, i.e., When $25-30 \%$ of the total dose of nitrogen is applied to top dressing for rice vegetation. In this case, the greatest effect is achieved with the introduction of nitrogen in the second stage of organogenesis, that is, in the phase of differentiation of the cone of panicle growth. This phase occur in different ways, after a certain time after flooding with water in different varieties (Ramazanova, 1993). For example, in the Marzhan variety it comes in 42 days, in the AySaule variety-after 38 days, in the Yantar variety-after 36 days. Nitrogen supplementation was carried out taking into account the characteristics of these varieties in this indicator.

Plant density before harvesting Yantar and AySaule grades was higher in variants with higher seeding rates. On the contrary, plant density of Marzhan was higher in cases with lower seeding rate.

Grade Marzhan in fertilizer application dose of $\mathrm{N}_{90+30} \mathrm{P}_{90}$ grain weight per plant at the seed rate to 6.5 million units/ha was $3.7 \mathrm{~g}$, the number of grain was 116.0 pieces; and a seeding rate of 7.5 million units was $2.9 \mathrm{~g}$, the amount of grain was 92.7 pieces and in grade Yantar at a rate of seeding 6.5 million pcs/ha of grain weight per plant was $3.3 \mathrm{~g}$, the number of grains was 100.8 pieces and a seeding rate of 7.0 million units/ha was $3.9 \mathrm{~g}$, the amount of grain was 124.8. In AySaule respectively at a rate of 6.5 million pieces of seeding was $3.6 \mathrm{~g}$, the amount of grain was 115.3 and seeding rate of 7.5 million units/ha was $3.7 \mathrm{~g}$, the amount of grain was 125.6 pieces (Table 4, Fig. 1). 
Zhazira Baiserikovna Zhumatayeva et al. / OnLine Journal of Biological Sciences 2017, 17 (2): 104.109 DOI: 10.3844/ojbsci.2017.104.109

Table 3. Rice variety productivity depending on type of seeding rate and doses of fertilizers

\begin{tabular}{|c|c|c|c|c|c|c|}
\hline \multirow[b]{2}{*}{ № } & \multirow[b]{2}{*}{$\begin{array}{l}\text { Name of } \\
\text { the variety }\end{array}$} & \multirow[b]{2}{*}{$\begin{array}{l}\text { Seeding rate, } \\
\mathrm{mln} . \mathrm{pcs} . / \mathrm{ha}\end{array}$} & \multicolumn{4}{|c|}{ Productivity, $\mathrm{t} / \mathrm{ha}$} \\
\hline & & & $\mathrm{N}_{0} \mathrm{P}_{0}$ & $\mathrm{~N}_{90} \mathrm{P}_{90}$ & $\mathrm{~N}_{90+30} \mathrm{P}_{90}$ & $\mathrm{~N}_{120} \mathrm{P}_{90} \mathrm{~K}_{60}$ \\
\hline$\overline{1}$ & Marzhan & \multirow{4}{*}{6.5} & 2.91 & 5.84 & 6.91 & 6.21 \\
\hline 2 & Yantar & & 2.75 & 5.94 & 6.43 & 6.40 \\
\hline 3 & AySaule & & 3.16 & 6.07 & 6.62 & 6.43 \\
\hline 4 & Marzhan & & 3.24 & 6.35 & 6.75 & 6.59 \\
\hline 5 & Yantar & \multirow[t]{3}{*}{7.0} & 3.39 & 6.59 & 7.05 & 6.88 \\
\hline 6 & AySaule & & 3.43 & 6.50 & 6.84 & 6.80 \\
\hline 7 & Marzhan & & 3.19 & 6.52 & 6.54 & 6.74 \\
\hline 8 & Yantar & \multirow[t]{3}{*}{7.5} & 3.26 & 6.70 & 7.10 & 6.95 \\
\hline 9 & AySaule & & 3.34 & 6.99 & 7.28 & 7.02 \\
\hline 10 & \multicolumn{5}{|c|}{ The lowest average $e_{05}-2.34$} & \\
\hline
\end{tabular}

Table 4. Elements of the rice varieties structure depending on seeding rates and doses of mineral fertilizers

\begin{tabular}{|c|c|c|c|c|c|}
\hline Grade & $\begin{array}{l}\text { Seeding rate, } \\
\text { mln pcs./ha }\end{array}$ & $\begin{array}{l}\text { Dose of } \\
\text { fertilizer }\end{array}$ & $\begin{array}{l}\text { Number of plants before } \\
\text { the harvest, pcs. } / \mathrm{m}^{2}\end{array}$ & $\begin{array}{l}\text { Productive tillering } \\
\text { pcs./plant }\end{array}$ & $\begin{array}{l}\text { Grain weight } \\
\text { ha/ plant }\end{array}$ \\
\hline \multirow[t]{12}{*}{ Marzhan } & \multirow{5}{*}{6.5} & $\mathrm{~N}_{0} \mathrm{P}_{0}$ & 336.0 & 3.2 & 2.9 \\
\hline & & $\mathrm{N}_{90} \mathrm{P}_{90}$ & 424.0 & 3.8 & 3.6 \\
\hline & & $\mathrm{N}_{90+30} \mathrm{P}_{90}$ & 477.2 & 4.4 & 3.7 \\
\hline & & $\mathrm{N}_{120} \mathrm{P}_{90} \mathrm{~K}_{60}$ & 448.0 & 4.2 & 3.5 \\
\hline & & $\mathrm{N}_{0} \mathrm{P}_{0}$ & 256.0 & 3.1 & 3.2 \\
\hline & \multirow[t]{4}{*}{7.0} & $\mathrm{~N}_{90} \mathrm{P}_{90}$ & 402.4 & 3.8 & 3.6 \\
\hline & & $\mathrm{N}_{90+30} \mathrm{P}_{90}$ & 458.4 & 4.3 & 3.9 \\
\hline & & $\mathrm{N}_{120} \mathrm{P}_{90} \mathrm{~K}_{60}$ & 445.2 & 4.2 & 3.6 \\
\hline & & $\mathrm{N}_{0} \mathrm{P}_{0}$ & 344.0 & 3.1 & 2.9 \\
\hline & \multirow[t]{3}{*}{7.5} & $\mathrm{~N}_{90} \mathrm{P}_{90}$ & 386.4 & 3.7 & 3.5 \\
\hline & & $\mathrm{N}_{90+30} \mathrm{P}_{90}$ & 440.0 & 4.2 & 2.9 \\
\hline & & $\mathrm{N}_{120} \mathrm{P}_{90} \mathrm{~K}_{60}$ & 458.8 & 4.1 & 3.6 \\
\hline \multirow[t]{12}{*}{ Yantar } & \multirow{5}{*}{6.5} & $\mathrm{~N}_{0} \mathrm{P}_{0}$ & 240.0 & 3.1 & 2.4 \\
\hline & & $\mathrm{N}_{90} \mathrm{P}_{90}$ & 400.0 & 4.2 & 3.2 \\
\hline & & $\mathrm{N}_{90+30} \mathrm{P}_{90}$ & 440.0 & 4.3 & 3.3 \\
\hline & & $\mathrm{N}_{120} \mathrm{P}_{90} \mathrm{~K}_{60}$ & 468.0 & 4.2 & 3.2 \\
\hline & & $\mathrm{N}_{0} \mathrm{P}_{0}$ & 269.2 & 2.8 & 2.6 \\
\hline & \multirow[t]{3}{*}{7.0} & $\mathrm{~N}_{90} \mathrm{P}_{90}$ & 445.2 & 4.3 & 3.0 \\
\hline & & $\mathrm{N}_{90+30} \mathrm{P}_{90}$ & 456.0 & 4.4 & 3.9 \\
\hline & & $\mathrm{N}_{120} \mathrm{P}_{90} \mathrm{~K}_{60}$ & 466.4 & 4.5 & 3.4 \\
\hline & \multirow[t]{4}{*}{7.5} & $\mathrm{~N}_{0} \mathrm{P}_{0}$ & 306.4 & 3.0 & 2.7 \\
\hline & & $\mathrm{N}_{90} \mathrm{P}_{90}$ & 420.0 & 4.0 & 3.0 \\
\hline & & $\mathrm{N}_{90+30} \mathrm{P}_{90}$ & 432.0 & 4.1 & 3.5 \\
\hline & & $\mathrm{N}_{120} \mathrm{P}_{90} \mathrm{~K}_{60}$ & 418.4 & 4.3 & 3.1 \\
\hline \multirow[t]{12}{*}{ AySaule } & \multirow{5}{*}{6.5} & $\mathrm{~N}_{0} \mathrm{P}_{0}$ & 210.4 & 3.2 & 2.7 \\
\hline & & $\mathrm{N}_{90} \mathrm{P}_{90}$ & 413.2 & 4.2 & 3.4 \\
\hline & & $\mathrm{N}_{90+30} \mathrm{P}_{90}$ & 437.2 & 4.2 & 3.6 \\
\hline & & $\mathrm{N}_{120} \mathrm{P}_{90} \mathrm{~K}_{60}$ & 402.4 & 4.3 & 3.7 \\
\hline & & $\mathrm{N}_{0} \mathrm{P}_{0}$ & 256.0 & 3.1 & 2.7 \\
\hline & \multirow[t]{4}{*}{7.0} & $\mathrm{~N}_{90} \mathrm{P}_{90}$ & 384.0 & 4.1 & 3.3 \\
\hline & & $\mathrm{N}_{90+30} \mathrm{P}_{90}$ & 424.0 & 4.2 & 3.6 \\
\hline & & $\mathrm{N}_{120} \mathrm{P}_{90} \mathrm{~K}_{60}$ & 440.0 & 4.3 & 3.2 \\
\hline & & $\mathrm{N}_{0} \mathrm{P}_{0}$ & 338.4 & 3.1 & 3.0 \\
\hline & \multirow[t]{3}{*}{7.5} & $\mathrm{~N}_{90} \mathrm{P}_{90}$ & 416.0 & 4.3 & 3.3 \\
\hline & & $\mathrm{N}_{90+30} \mathrm{P}_{90}$ & 453.2 & 4.3 & 3.7 \\
\hline & & $\mathrm{N}_{120} \mathrm{P}_{90} \mathrm{~K}_{60}$ & 450.4 & 4.5 & 3.3 \\
\hline
\end{tabular}

Cultivar Marzhan and Yantar with a seeding rate of 6.5 million units/ha dose $\mathrm{N}_{90+30} \mathrm{P}_{90}$ productive tillering was $4.3-4.4$, whereas with seeding rate of 7.5 million units/ha with the same dose of productive tillering was
4.2. In the variety AySaule with seeding rate of 6.5 million units/ha dose of $\mathrm{N}_{90+30} \mathrm{P}_{90}$ productive tillering was 4.2 and a seeding rate of 7.5 million units/ha dose of $\mathrm{N}_{90+30} \mathrm{P}_{90}$ productive tillering it was 4.5 (Fig. 2). 

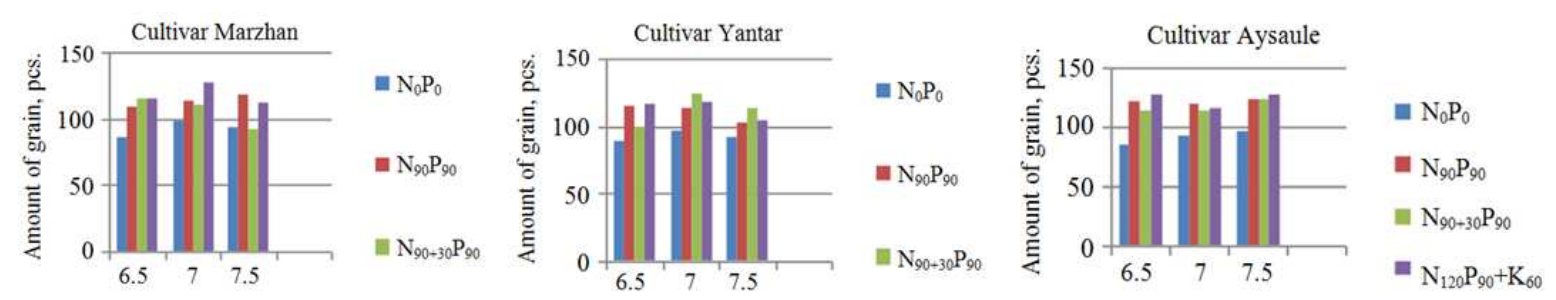

Fig. 1. The number of grains in the main panicle depending on seeding rates and doses of fertilizers
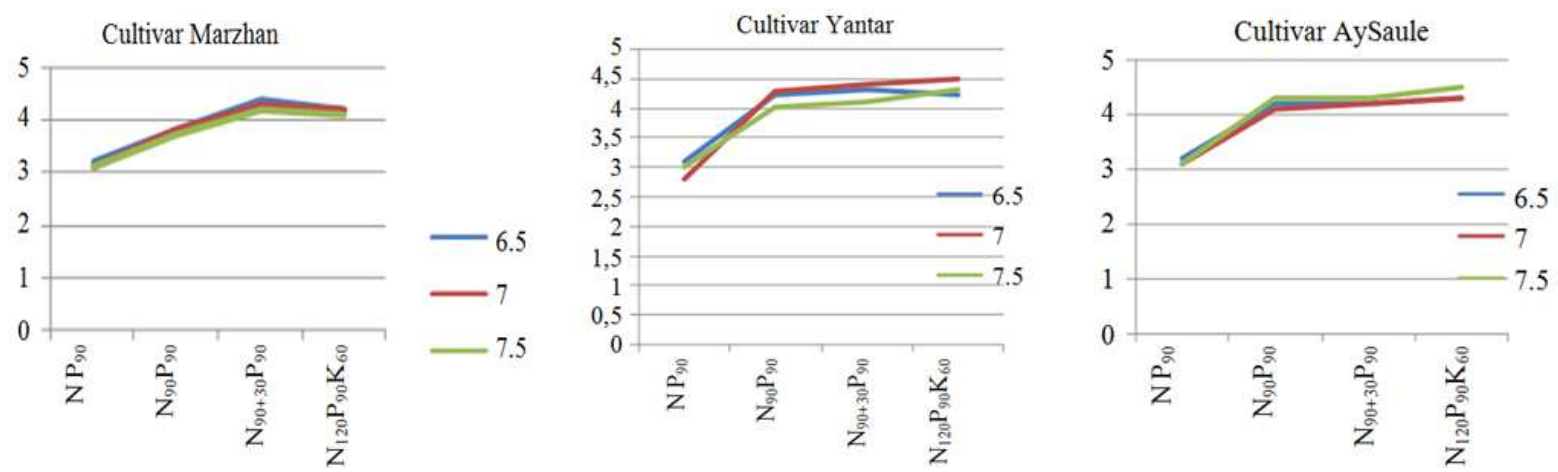

Fig. 2. Productive tillering varieties of rice depending on seeding rates and fertilizer dose

The results of the structural analysis show that the varieties Marzhan and Yantar responded negatively to increase the seeding rate, reducing the productive tillering in the background $\mathrm{N}_{90+30} \mathrm{P}_{90}$ by $8 \%$ and grade AySaule conversely, in such circumstances, the tendency to its growth by $28 \%$. More precisely plant productivity is correlated doses of fertilizers; in addition, Marzhan grade in fertilized variants was an increase in plant lodging, which increases the risk of loss during harvesting.

\section{Conclusion}

From a study of recognized varieties of local cultivar AySaule forms the highest yield $(7.28 \mathrm{t} / \mathrm{ha})$ at a rate of $7.5 \mathrm{mln}$ pcs./ha with a dose of fertilizer $\mathrm{N}_{90+30} \mathrm{P}_{90}$.

A variety Yantar generates the highest yield (7.05 $\mathrm{t} / \mathrm{ha}$ ) at a rate of seeding 7.0 million units/ha with a dose of fertilizer $\mathrm{N}_{90+30} \mathrm{P}_{90}$ and Marzhan variety produces the highest yield (6.91 t/ha) with a lower rate of seed $(6.5$ mln. pcs./ha) with a dose of fertilizer $\mathrm{N}_{90+30} \mathrm{P}_{90}$.

Efficiency of fertilizers in all the studied varieties manifested through increased grain weight per plant and productive tillering.

\section{Acknowledgement}

As a result of experiments, scientists found out that according to all indicators the best innovative variety of rice is AySaule, which gives a good harvest in the salt soil.

\section{Funding Information}

The experiments were supported by funding from the Kazakh research institute of rice growing of Zhakhayev, Kyzylorda city, Kazakhstan.

\section{Author's Contributions}

We certify that all persons who have made substantial contributions to the work reported in this manuscript.

Zhazira Baiserikovna Zhumatayeva, Asset Myrzakhanuly Toktamyssov, Kurmanbek Bakiruly: They conducted field researches, made the literary review, analyzed and interpreted the results and drew conclusions.

EImira Shoraevna Yeleuova: She edited tables and drawings, printed the text and wrote the conclusion according to tables.

Murat Orlenbaevich Nassimov: He carried out all technical and organizational works.

\section{Ethics}

The manuscript represents original and valid work and does not infringe or violate any copyright agreements or any other personal or proprietary rights and neither this manuscript nor one with substantially similar content has been published or is being considered for publication elsewhere; copies of closely related manuscripts are provided. 


\section{References}

Agarkov, V.D., A.C. Udzhuhu and E.M. Kharitonov, 2006. Agro-technical requirements and standards in rice growing. Rice Res. Institute, Krasnodar.

Aleshin, E.P and A.I. Aprod, 1960. The effect of temperature on the seed germination of rice varieties, Kuban production. Plant Physiol., 7: 358-362.

Dospehov, B.A., 1973. Methods of Field Experience. 1st Edn., Moscow, Kolos, pp: 335.

Dzhulay, A.P., 1956. The Development of Rice Culture Farming with Periodic Irrigation. 1st Edn., Sovetskaya Kuban, Krasnodar, pp: 136.

Erygin, P.S., 1950. Physiological Basis of Rice Irrigation. 1st Edn., Leningrad, Moscow, pp: 207.

Iskhakov, T.Z., 1969. An Influence of Sowing Dates on the Growth, Development and Productivity of Certain Varieties of Rice under the Tashkent Area. 1st Edn., Tashkent, pp: 27.

Kirichenko, K.S., 1944. Rice Irrigation. 1st Edn., Krasnodar, pp: 14.

Koutroubas, S.D., F. Mazzini, B. Pons and D.A. Ntanos, 2004. Grain quality variation and relationships with morpho-physiological traits in rice (Oryza sativa L.) genetic resources in Europe. Field Crops Res., 86: 115-130.

Kruzhilin, I.P., V.V. Melikhov and M.A. Ganiev, 2005. Resource-Saving Irrigation Technology of Rice Irrigation in Volgograd Region. In: Collection Scientific Article: Irrigation of Land and Water-Saving Technologies of Cultivation of Agricultural Crops, Publishing House of the Volga, Volgograd, pp: 70-78.
Khatkov, K.K., 2009. The dependence of the nitrogen content in rice plants from seeding norms and doses of nitrogen fertilizer. Agric. Vestnik Uralsk, 1: 56-58.

Li, J.M., J.H. Xiao, S. Grandillo, L.Y. Jiang and Y.Z. Wan et al., 2004. QTL detection for rice grain quality traits using an interspecific backcross population derived from cultivated Asian ( $O$. sativa L.) and African (O. glaberrima S.) rice. Genome, 47: 697-704.

Sheudzhen, A.H., T.N. Bondareva and V.V. Anoshenkov, 2001. Methods of Seed Germination Increase and Rice Productivity. 1st Edn., Maikop, pp: 4.

TCVRBI, 2007. The Catalog of Varieties of Rice Breeding Institute. 1st Edn., Krasnodar, pp: 47.

Ramazanova, S.B., 1993. Nitrogen Nutrition and Productivity of Rice: The dissertation Doctors of Biological Sciences: 06.01.04. 1st Edn., Moscow, pp: 339.

Vlachos, A. and I.S. Arvanitoyannis, 2008. A review of rice authenticity/adulteration methods and results. Crit. Rev. Food Sci. Nutr., 48: 553-598.

Velichko, E.B. and K.P. Shumakova, 1972. Watering Rice Without Flooding. 1st Edn., Kolos, Leningrad, pp: 86.

Witte, P.A., 1930. Materials for the Issue of Rice Cultivation in the North Caucasus. 1st Edn., Novocherkassk, pp: 150. 